\title{
TRAINING IN ISLAMIC RITUALS: A SOLUTION TO MUSLIM EXTREMISM
}

\author{
Mohammad Ismath Ramzy \\ University of Malaya, Malaysia
}

\begin{abstract}
The rise of radical movements and its rhetorical advocacy to reconstruct Muslim society raised the question on the connection between religion and extremism. The majority of policy makers and social scientists seem to be convinced that increasing religious awareness among the Muslims have led to violence against others. Hence, the war against terrorism targets religious awareness among the Muslims and use strategies to secularize Muslim societies. However, secularization in the Muslim world has increased violence instead of decreasing it. This article puts forward that religious awareness and Islamic practices such as fasting during the month of Ramadhan can increase peace and harmony instead of violence. The recent statistics on religion and extremism also authenticate the positive aspect of religiosity and harmonious living.
\end{abstract}

Keywords: Islamization, radicalism, war on terror, peace, fasting, Ramadhan and ruhaniyyah.

\section{Introduction}

Outspoken extremists spreading religious rhetoric and their commitments in religious practices have led many in the West to believe that Islam motivates exclusivism and terrorism. Gary Langer' polls report conducted by ABC News in 2009 found that $29 \%$ of Americans believe Islam encourages violence against non-Muslims (Cordesman, 2009, p. 1$10)$. 
Saunders' (2012) on Western perception on Muslims also alluded to this discernment and wrote,

"Jihadist terrorists are religious believers: that much is undeniable. They invoke Allah and the Koran, they denounce their targets for being unholy, they speak of a divine calling and a scriptural obligation to avenge the 'crusader' and the 'infidel'."

(Saunders 2012)

According to him, the general assumption is that Jihadists are believers in Islam, practicing Muslims and their commitment in religion instigates violence against non-Muslims and the Quran vindicates killing of non-Muslims. Under the influence of this perception, they consider the terrorist movements as essentially religious and any devout Muslim could potentially become a terrorist. Hence, they perceive Muslims who believe in God and practise Islam have to retaliate against non-Muslims. Yeşilada and Noordijk (2010) also posted similar phobia on Islam in Turkey. They endorsed increasing religious awareness among the Turkish is a threat to non-Muslims. They support their argument with the data from the World Values Surveys.

The people not only in the West but also in the East consider Islamization as a threat to the security. The anti-Muslim sentiment in Myanmar, Sri Lanka, India, Thailand and other Asian countries is also interpreted as conveying this fear for national security. Even in movies, Islamophobia has well demonstrated in the Bollywood movie 'Vishwaroopam' or 'Vishwaroop' in Hindi (S. Chandrahasan et.al, 2013). This emerged as the second highest grossing movie in India. Haqqani (2006) also envisioned the rise of Muslim radicalism in Indian sub-continent as a threat to Indian government. He wrote,

"Has democratic India "solved" the problem of radical Islam? Despite India's clear successes in this regard, Islamist radicals continue to organize and operate outside the political mainstream. While an overwhelming majority of Indian Muslims have stayed away from radical Islamist groups, extremist Islamists remain a threat to India's stability much in the same way that they threaten democratic societies in the West." 
According to Haqqani (2006), radical groups are operating outside democratic system in India and a threat to national security.

Though these assumptions require more academic investigations, it shows that the extremists' commitment in Islamic rituals and worships have shaped non-Muslims' perception on Muslims (Mogahed, 2006). Further, the large number of recruitments from Islamic religious seminaries to extremist groups like the Taliban ${ }^{1}$ and a few religious school graduates were among the people who were arrested in Malaysia (UM Lecturer preached martyrdom and holy war, 2014) as well in Singapore (Mukhlis Abu Bakar, 2009) and their association with extremist groups tend to contribute to a negative perception on Muslims among the non-Muslims.

It should be noted that following the generalised view quoted earlier, Saunders' (2012) pointed out that after a decade of counterterrorism research, scholars have reached two unambiguous conclusions - (i) those who become terrorists are generally not the devout or fundamentalist Muslims and (ii) they are not driven by religious faith, rather by political belief. Of more significance is that Muslims who advocate to violence and terrorism are worlds apart from those who are most religious or fundamentalist and are opposed to each other's approach.

Yet policy makers and social scientists continue to be convinced that religious awareness among the Muslims motivates violence and they suggested replacing Muslims' worldview with secularism as a strategy to challenge extremism in the Muslim world. Consequently, they crayoned policies for secularization of Muslim societies (Mogahed, 2006).

\section{Western strategies to secularize the Muslim world}

The experience with Christendom during the Middle Ages and the struggle to determine self-right in the West led social scientists to consider religion as a potential to cause violence. Indeed, the West attained socio-economic and political development when the West was liberated from the hegemony of Christianity (Muhammad Naguib alAttas, 1993). Sociologists and economists in the West considered this religion as great obstacle for economic growth and social development.

Prominent scholars in the West like Karl Marx (1818-1883), Emile Durkheim (1858-1917), and Marx Weber (1864-1920) shared a common concern to identify religion as a challenge to economic growth. Marx (1978) downplayed the role of religion by describing it as 'opium'. He 
wrote, "Religion is the sigh of the oppressed culture, the heart of a heartless world, just as it is the spirit of a spiritless situation. It is the opium of the people" (p. 54). He describes the religion as a mechanism to deviate the mass from the truth like opium that provides a temporary happiness to the user while destructing the prolong life and health. Ozcan (1995) explained in detail on the process of restraining the role of religion in the spare of economy from the Western world.

Arthur Lewis's (1915-1991) theory of Economic Growth also found a similar conclusion. According to him, religion, as it preaches asceticism and the virtuous benefits of consuming less rather than more, plays negative role in socio-economic development (as cited in Deneulin \& Shahani, 2009, p. 262). Further, religion becomes an obstacle to economic growth, Lewis argues, when it imbues people with certain negative attitudes towards wealth-accumulation and economic growth. A religious society that fails to see wealth as a means to achieve social status or condemns the search for higher status as being sinful may not have favourable conditions for economic growth. Population expansion, which growth theories have considered to be a significant hindrance to economic growth, can also be negatively affected by religious attitudes towards contraception and family planning (p. 262). In brief, religion, in the view of Lewis, not only disturbs economic development but also plays a deleterious role by encouraging early pregnancy and challenging family planning.

Thus, these Western scholars identified the need of liberating their mind and land from the influence of religion. They used secularism as a mechanism to carry out the plan as explained by Berger (1993). According to him, secularism is "the process by which sectors of society and culture are removed from the domination of religious institutions and symbols" (p.113). Thus, secularism has provided an opportunity for the West to develop their society and hasten economic growth. The West, as described by Jacques Maritain, articulated this reason and produced economic and social upliftment after having acquitted the society from the influence of Christianity (Muhammad Naguib al-Attas, 1993).

Socialists like David Hume (1711- 1776), Engels (1820-1895), Nietzsche (1844-1900) and Lenin (1870-1924) in addition to Karl Marx, Emile Durkheim and Marx Weber postulated the 'death' of religion in the face of economic growth and improved standard of living (Patrick, 2012). This experience in the West has asserted sociologists to practice similar methodology to combat religious extremism in the Muslim world. 


\section{Secularization of the Muslim World}

Secularization of the Muslim world started in the beginning of 13th century during the Umayyad period (661-750 CE) (Qutb, 2006) and it dominated the Muslim institutions in 20th century through the educational system (Muhammad Naguib al-Attas, 1993, p. 97-109). According to Oliver Tschannen (1991), secularization is processed at three levels, namely, Macro - social differentiation; Meso - decline in significance of religion in organizations; and Individual - a reduction in levels of practice, belief or affiliation at the individual level (p. 395415).

At the first level, sociological theories were introduced through education and literature. Auguste Comte' Positive Philosophy, for instance, challenged the notion of the sacred in society. According to this theory, all phenomena are subjected to invariable natural laws including social order. Thus, social changes embrace three transformation stages, that is, fetishism, polytheism and monotheism. In this perspective, humanity passes through the ages of fetishism and polytheism and lives in superhuman power world depriving the power of God (Turner, Beeghley \& Powers, 2011, p. 40-43). Therefore, religious beliefs and practices are irrelevant today as they are categorized as primitive culture. Rostow's stages of growth also considered religion as an affair of a traditional society and have no room in the modern arena (Rostow, 1962, p. 38-40). Emile Durkheim's social differentiation theory also ousted religion from the society's mainstream (Turner, 1981). Max Weber identified religion as a mechanism to perpetuate class domination and argue for disappearance of religious influence with the advancement of materialism (Weber, 1993). Thus, these secularization theories tend to challenge contemporary sacred social institutions by privatizing faith and corrode the influence of religion and its authority (Casanova, 1994, p. 10).

Modernization introduced 'culture shift', an advance version of secularism to eradicate traditional value system. Cultural shift was expected with the progress of world economy and advance of infrastructure confiscating religious values. Ronald Inglehart and Wayne Baker (1997) wrote, 
"Modernization theorists ... have argued that the world is changing in ways that erode traditional values. Economic development almost inevitably brings the decline of religion, parochialism and cultural differences"

Liberalism is another mechanism to pause religious authority in society. Berger, for instance, argues that religious consciousness in the society will be eradicated not only by science but also by the expansion of social and cultural pluralism ${ }^{2}$ and liberalism (Berger, 1967). According to him, multiple religious and secular groups in a liberal society fight for influence on the basis of philosophical and ethical claims. This claim ultimately leads to the privatization of religion (pp. 328).

These secular theories on social change became influential in the Muslim world and was integrated into the education system. Thus, Muslims became slaves for secular intellectual properties and academic investigations. Muhammad Naquib al-Attas (1993) identified 'loss of $a d a b$ [that is, ] loss of discipline' as a primary consequence of secularization in the Muslim world. According to him, loss of adab has eradicated Islamic values and principles in education, politics, economic and other social sciences (pp. 97-109). In the view of Muhammad Qutb (1919-2014), loss of interest in 'bidding the good and forbidding the evil' as prescribed in the Quran ${ }^{3}$ offered a room for secularism in the Muslim world. He explained the gradual process of secularization in the Muslim world epitomizing Egypt (Qutb, 2006, p. 75-102). Both of these scholars found the grave consequences of secularism in Aqidah- Muslim mind or Islamic thought ${ }^{4}$.

\section{Secularization increased terrorism}

Contrary to prediction, secular ideologies like liberalism, communism, socialism and capitalism in the Muslim world did not improve material development and social justice (Juergensmeyer, 1993, p. 110-118). The majority of Muslim countries still remain poor, sometimes below the poverty line. The social justice also is questionable in the Muslim world.

Secularism also did not solve the problem of extremism in the Muslim world. Instead, it increased by impacting on al-wasatiyahbalance approach in Muslim thought. Thus, secularization posted a 
significant threat to the core nature of religion particularly characteristics of wasatiyyah-balance approach and caused laxity as well as extremism.

Laxity created ignorance on religion and religious practices in particular Islamic approach in social sciences as well as Islamic teaching on Muslims and non-Muslim relation and Islamic shariah (Qutb, 1964). Later, some group of Muslims used excessive approach as synthesis of negligent (Samuel, 2013). Thus, instead of waning extremism, secularism promoted it as observed by McGoldrick (2006). He wrote 'religion has assumed a growing salience in the politics of countries around the world' (p. 168).

Jonathan Fox showed number of interrelated process that caused increasing trend of religious extremism. Failure of secular ideologies as indicated before, backlash of religious tradition against modernization, individuals' experience with secularism, inclusive approach of religion, politicizing religion, increasing religiosity due to freedom of choice, use of religious institutions for political mobilization, interpersonal and inter organizational networks, and advanced communication technology are few reasons increased the influence of religions in the society (Fox, 2005, p. 15).

Berger, the noticeable advocate of the secularization, recently wrote, "Our age is not an age of secularization. On the contrary, it is an age of exuberant religiosity, much of it in the form of passionate movements with global outreach" (Berger, 2002, pp.7-20). Contrary to social scientists prediction, religion extremism is increasing as a consequence of secularism. Rodney Stark confirmed the failure of secularization thesis. According to him, the decline in religious belief and participation is a myth. It is because; "there has been no demonstrable long-term decline in European religious participation" and "levels of subjective religiousness remain high (Stark, 1999).

It shows religious awareness came into the Muslim world, challenging secularism and emanated it with force. This force shook the base of wasatiyyah-balance approach and created many school of thoughts and trends among the Muslims. The central of these schools of thought was theological investigation and the application of the shariah. H. Gibb, W. Smith, A. Hourani, L. Binder, H. Mintjes and R. Humphrey classified these schools of thought into traditionalism/fundamentalism, modernism and secularism ${ }^{5}$. Zubaida (2010) discussed the formation of these schools and trends and explained the variation (p. 270-295). The emphasis on Islamic shariah without proper theological and spiritual background produced extremism (Mogahed, 2007). The balance 
approach or wasatiyyah approach on Islamic shariah with proper theological, intellectual and spiritual training will provide the solution for issues in the Muslim world including extremism.

Thus, religious awareness and religious consciousness as perceived by many will not lead to extremism and violence. The commitment in religious practices also did not instigate violent activities. However, lack of knowledge in reading religious scriptures and inadequate training in Islamic shariah, in addition to other socio-political reasons discussed below, tend to lead many towards extremism.

\section{Islam and religiosity}

Perversely to social scientists, the religious awareness among the Muslims and conviction in faith, indeed, increases openness and inclusivism. Islamic practices widen the perspective and encourage coexistence articulating spiritual connection between the God and humanity. Fasting in Ramadhan, for instance, is a mechanism to control craving, anger and to develop patience, love and kindness in social interaction.

Fasting is one of the five pillars of Islam (arkān al-Islām). Prophet Muhammad (PBUH) points out that,

"Islam has been built on five [pillars]: testifying that there is no God except Allah and that Muhammad is the Messenger of Allah, establishing the Salaah (prayer), paying the Zakah (obligatory charity), making the Hajj (pilgrimage) to the House, and fasting in Ramadan."

(Bukhari, 1997, Hadith No. 5203)

This Hadith describes fasting as one of the pillars of Islam. Observing fasting is not only a means to express ones' commitment in religion as an obligatory ibadah but also to prove a person's conviction and commitment. The goal of fasting has been clearly explained in the Quran. Allah SWT says, "O Believers, the Fast has been made obligatory on you just as it was prescribed for the followers of the Prophets before you. It is expected that this will produce taqwa, piety in you." ${ }^{, 6}$ Fasting is a mechanism prescribed by God throughout the history to develop ones' commitment in faith and to strengthen his relationship with God.

Thus, fasting is a spiritual training program prescribed by Allah (SWT) to change a believer from the control of desires or animal 
temptations (Hayawaniyyat) (Syed Muhammad Naquib al-Attas, 1990, p. 7 - 9) to authority of God (Rabbaniyyat) (al-Qaradawi, 1985, p. 7). As a collective Ibadat, fasting seeks to bring a kind of spiritual bond between fellow Muslims, which is known as Ruhaniyyat. This is further illustrated in another hadith,

"Fasting is a junna-protects from following the harm of desires. So if one of you is fasting then don't use repugnant speech nor squabble. Thus, if a person curses you or tries to fight with you say (to yourself) I am fasting, I am fasting". ${ }^{7}$

Fasting, according to this Hadith by Prophet Muhammad (PBUH), is a mechanism to control the desires and self-motivations.

Fasting is prescribed in the month of Ramadhan - a unique month in Islamic calendar especially designed by Allah SWT to ease the train the nafs-human psyche, ego or soul and human desires by tiding up Shaitan and reducing his influence. It is further explained in another hadith. Allah's Messenger (saws) said,

Ramadan, a blessed month, has come to you during which Allah has made it obligatory for you to fast. In it the gates of Heaven are opened, the gates of al-Jahim are locked, and the rebellious devils are chained. In it Allah has a night which is better than a thousand months. He who is deprived of its good has indeed suffered deprivation. ${ }^{8}$

The month of Ramadhan, in the view of this hadith, has especially made by God to train the nafs. So, He blocked the ways that the nafs would be allured to prioritize desires than the guidance of Allah SWT. On the other hand, Allah SWT has made this month to encourage good deeds and promised many fold incentives for merits. A companion of the Prophet said that the Messenger of Allah addressed us (i.e. the companions) on the last day of Sha baan, saying,

"Oh people! A great month has come over you; a blessed month; a month in which is a night better than a thousand months; a month in which Allaah has made it compulsory upon you to fast (by day), and voluntary to 
pray by night. Whoever draws nearer (to Allaah) by performing any of the (optional) good deeds in (this month) shall receive the same reward as performing an obligatory deed at any other time, and whoever discharges an obligatory deed in (this month) shall receive the reward of performing seventy obligations at any other time. It is the month of patience, and the reward of patience is Paradise. It is the month of charity, and a month in which a believer's sustenance is increased. Whoever gives food to a fasting person to break his fast shall have his sins forgiven, and he will be saved from the Fire of Hell, and he shall have the same reward as the fasting person, without his reward being diminished at all".

Thus, fasting is not merely a regular ritual but also a training programme to develop self-control, to instigate taqwa, that is, God consciousness in all affair of life. So, the month of Ramadhan is portrayed as an 'open air Ibadah camp' in which every member of the Muslim community will be thinking and doing same thing, hoping for the same goal; all to seek the pleasure of Allah, thus, suppressing the propensity to commit sin. Allah SWT states, "O ye who believe! Fasting is prescribed for you, as it was prescribed for those before you, so that you may become righteous." 10

\section{Fasting and Inclusiveness}

Allah SWT wants to guide the believers towards the straight and middle path (al-wasat) by answering to his prayers 'Ihdina Sirat al Mustaqimdirect us on to the Straight Way'. ${ }^{11}$ However, transformation of a person from the status of believer to the status of pious and God-consciousness is impossible if he is controlled by his desires and temptations ${ }^{12}$. So, he should be free from all kinds of controls and dominations and is ready to submit to the will of God. If he does so, the guidance of Allah and the Quran will be beneficial to him. Allah SWT said in the beginning of Surah al-Baqarah, "this is the Book of Allah: there is no doubt about it. It is guidance to God-conscious people". ${ }^{13}$

Therefore, Allah SWT has chosen the month of Ramadhan to reveal his guidance, the Quran in which Muslims undergo a severe training programme to control their desires and submit to themselves to the will 
of God. Allah SWT states, "Ramadan is the month in which the Qur'an was sent down: this Book is a perfect guidance for mankind and consists of clear teachings which show the right way and are a criterion of Truth and falsehood." ${ }^{14}$ So, there is a strong connection between Fasting, Ramadhan and the Quran.

Now the challenge is Shaitan. He uses different tactics to stop Muslims to be pious and serious and to make intimate relationship with the Quran. Sometimes he does not disturb fasting or its ritual. However, he deceives saaim, the person who observes fasting, from promoting good deeds and to divert from achieving the supreme goal of fasting as mentioned in the Quran, "Shaitaan promises nothing but deception". ${ }^{15} \mathrm{He}$ preoccupies the minds of saaim with things that are of no real importance. He tempted to give more attention on issues related to rituals rather than Taqwa, God consciousness or spiritual well being. As the result, saaims some time occupy in fighting for unresolvable figh issues regarding on certain Ibadath as observed during Ramadhan to the extent of identifying the month of Ramadhan as the month of fighting by nonMuslims beginning from sighting of the moon.-The closeness with Allah SWT will reflect in social life when constructing cordial relationship with fellow Muslims and non-Muslims based on love, compassions and acceptance. This spiritual relationship is known as Ruhaniyyat (Syed Muhammad Naquib al-Attas, 1990) Ruhaniyyat is an Arabic word which literally translates to something along the lines of "Spiritualism/Spirituality" to denote feelings and emotions like happy, sad, awe, reverence, hate, anger, love, and so on.

In the view of Al-Ghazzali, it is spiritual expression of human soul. $\mathrm{He}$ called it as al-Latifah al-Ruhaniyah (spiritual subtlety) which sets men are apart form other living things (Syed Muhammad Naquib alAttas, 1990). It serves the purpose of Islamic ritual practices. The important aspect of ruhaniyya is doing justice to Muslims and nonMuslims as indicated by Al-Attas, when he explained the objectives of Islamic education (Syed Muhammad Naquib al-Attas, 1980, p. 10). The ruhaniyyah expression, thus encourages inspirational genteel, sensitive, elegant, compassionate and humane.

When a Muslim trains his nafs-soul and accepts Quranic guidance, he becomes closer to Allah SWT. In other words, he becomes Rabbani-a man with qualities of Rab. This rahbanniyah will reflect in his social life. So, he would be broad, accept people and respect fellow brothers and sisters. Thus, number of ibadat is not important in the month of 
Ramadhan, rather acquiring God satisfaction through articulating taqwa is essential.

So, fasting is a training course to strengthen Taqwa, consciousness of God or Rabbiniyyat (al-Qaradawi, 1985, p. 7). The month of Ramadhan is especially designed to encourage this motivation in all walks of life. In order to do so, Allah has tied up Shaitan (Evil) during Ramzan and gives more rewards to the merits. Taqwa-God consciousness in social life reflects in the form of Ruhaniyyat (Syed Muhammad Naquib al-Attas, 1990). Prophet Mohammad, the best model for ruhaniyyah, therefore, was perfect example in compassionate, loving kindness and other as prescribed in the Quran ${ }^{16}$ and in the history. ${ }^{17}$ His exemplary relationship has lauded by Muslims and non-Muslims (Qasim, 2014).

God expects ruhaniyyah relationship with fellow human being, Muslims and non-Muslims, from a Muslim who acquired Taqwa by performing rituals. ${ }^{18}$ Failure to construct ruhaniyyah relationship with fellow human being including non-Muslims shows weakness in understanding the faith and practicing rituals. Thus, Islamic rituals must encourage a Muslim to construct Ruhani relationship with fellow Muslims and non-Muslims and to become 'Good and broad minded human being in day-to-day dealings.

However, the reports on extremism among the Muslims say otherwise even though they observe Islamic faith and practice rituals. The PEW report in 2007 endorsed that the Muslims in the United States continue to reject extremism and only $1 \%$ of them justified attack on civilians. This report also found $94 \%$ of Muslims in German do not support attacks on civilians while $94 \%$ of religious Muslims in France objected attacks on civilians. In Britain, $90 \%$ of religious Muslims rejected the attacks while $87 \%$ of the nonreligious disapproved it (Pew Research Center, 2007).

Indeed, recent reports on radicalism confirmed that lack of proper theological, intellectual and spiritual training lead to extremism. The British intelligence agency MI5 conducted a survey in 2008 and confirmed no role for Muslim clerics in the indoctrination of terrorism (Saunders, 2012). According to this report, majority of people who involve in terrorist activities are religious novices and have not been raised in religious households.

"Far from being religious zealots, a large number of those involved in terrorism do not practise their faith regularly. Many lack religious literacy and could actually 
be regarded as religious novices. Very few have been brought up in strongly religious households, and there is a higher than average proportion of converts"

(MI5 report challenges views on terrorism, 2008)

It means the people who subscribed to radicalism have no religious motivation even though they claim themselves as religious devotees. The report further says that many of them were found to be involved in activities against Islamic teachings like taking drugs, drinking alcohol and visiting brothels. The report says, "Rather than intense monastic religious devotees, they tend to be non-faithful individuals who are drawn to radical peer groups for political or personal, but not religious, reasons" (Saunders, 2012).

Lack of proper understanding of Islam also contributed to exclusive approach on others (al-Qaradawi, 2006). The British Security Service report also endorsed it and said that radicalism in the Muslim society is an outcome of misunderstanding some of Islamic concepts. The report notes,

"One of the key issues in the debate concerning the role of religion in the radicalisation process is the interpretation of Islamic texts and the meaning given to particular passages and verses (i.e. sword verses) and the significance of key concepts (such as Jihad)".

(Christman, 2012, p. 42)

The texts of the Quran and Hadith related to Jihad and infidel were interpreted without considering the historical and social context misguided the young generation and motivated to radicalism.

Conversely, the case study of fasting in the month of Ramadhan explained that Islamic rituals and practices promote coexistence. Muslims who conceived Islam from a good teacher and raised in a religious family do not subscribe to radical Islam arguing that these doctrines misappropriate religious labels for violent ends Rather they protect others against violent radicalization (Christman, 2012).

\section{Conclusion}

The extremists' position on religion has misled many to consider Islam as potential of violence. The social scientists seem to suggest 
secularization of Muslim societies as a solution. The campaign 'War on Terror' was introduced as a strategy to the secularization process. However, secularization pushed the younger generation in the Muslim world into radicalism and extremism.

Islamic movements and institutions have to arrange proper spiritual training for the youths and to ensure benefits from Islamic rituals and worships. Proper academic and spiritual training with the emphasis on alwastiyah-balance approach to the religious scriptures, namely, the Quran and Hadith, is recommended to control extremism in the Muslim world. Islamic religious schools and academic institutions have to produce literatures on Islamic theology and shariah based on wasatiyah and make available in online for the youths. Awareness in religion encourages inclusivism as demonstrated in the worship of fasting during Ramadhan. The reports on Muslims and radicalism also exposed the role of religious awareness in promoting moderation and coexistence.

\section{Endnote}

1 Ahmed Rashid, "The Taliban: exporting extremism." FOREIGN AFFAIRS-NEW YORK- 78 (1999): 22-35 and John Simpson, Who are Thaliban, BBC NEWS-Asia, 1 November, 2013, Retrieved from: http://www.bbc.com/news/world-south-asia-11451718.

${ }^{2}$ Pluralism refers to the amount of religious diversity in a given area. Rather than being a simple count of the number of different religions, it is typically defined as the amount of "evenness" with regard religious affiliation in an area.

${ }^{3}$ Al Quran, 3:104

${ }^{4}$ Muhammad Qutb. Manhaj al-tarbiyah al-islamiyah-Islamic Education, Eygpt: Dar al-Qalam, 1980 and Muhammad Naguib Al-Attas, The Concept of Education in Islam a Framework for an Islamic Philosophy of Education, Kuala Lumpur: International Institute of Islamic Thought and Civilization (ISTAC), 1991.

${ }^{5}$ Binder, Leonard. Ideological Revolution in the Middle East, New York, 1964, 31-40 and Mintjes, H. "Mawlana Mawdudi's Last Years and the Resurgence of Fundamentalist Islam," Al-Mushir 22.2 (1980), 46-73.

${ }^{6}$ Al-Quran, 02:183

${ }^{7}$ Al-Bukhari, 2264.

${ }^{8}$ Al-Tirmidhi, Abu'Isa, Sunan al-Tirmidhi. Beirut: Dar Ihya'al-Turath, 1986, Hadith no: 1962 
9 Abi Bakr Muhammad Ibn Ishaq Ibn Khuzaymah, Sahih Ibn Khuzaymah, Abi 'Abd Rahman 'Adi (Ed.), Beirut: Dar Al-Kotob AlIlmiyyah, 2002, Hadith no: 1887.

${ }^{10}$ Al-Quran, 02:183

${ }^{11}$ Al-Quran, 01:06

${ }^{12}$ Al-Quran, 45:23

${ }^{13}$ Al-Quran, 02:02

${ }^{14}$ Al-Quran, 02:185

${ }^{15}$ Al-Quran, 04:120

${ }^{16}$ Al-Quran, 68:04

${ }^{17}$ Muhammad Hamidullah, "Relations of Muslims with non-Muslims." Journal Institute of Muslim Minority Affairs 7.1 (1986), 7-12 and Abu Salman Deya ud-Deen Eberle, The Universal Mercy of the Prophet Muhammad's Mission, Muslim World League, n.d. Retrieved from: http://mercyprophet.org/mul/sites/default/files/UniversalMercyEng.pdf

${ }^{18}$ Al-Quran, 29:45

\section{References}

Berger, P. L. (2002).Globalization and religion.Hedgehog Review,4 (2), Retrieved from http://iascculture.org/THR/hedgehog_review_2002-Summer.php

Christmann, K. (2012). Preventing Religious Radicalisation and Violent Extremism: A Systematic Review of the research evidence.UK: Youth Justice Board for England and Wales 42. Retrieved from https://www.gov.uk/government/uploads/system/uploads/ attachment_data/file/396030/preventing-violent-extremismsyste matic-review.pdf

Cordesman, A. H. (2000). ABC News/Washington Post Poll on US Views of Islam: Key Trends. Centre for Strategic and International Studies (CSIS), 1-10. Retrieved from: http://csis.org/files/media/csis/pubs/090421_islampollreport.pdf

Esposito, J. L. and Mogahed, D. (2007). Who speaks for Islam?: What a billion Muslims really think. New York: Gallup Inc.

Fox, J. (2005). Religion, civilization, and civil war: 1945 through the new millennium. Lanham, MD: Lexington Books.

Hedgehog Review, 4(2). Retrieved from http://iasc-culture.org /THR/ hedgehog_review_2002-Summer.php 
McGoldrick, D. (2006). Human rights and religion: The Islamic headscarf debate in Europe. Hart Publishing.

Mukhlis Abu Bakar. (2009). Islamic Religious Education and Muslim Religiosity in Singapore, in Banks, J. A. (Ed.). The Routledge International Companion to Multicultural Education. New York: Routledge, 437-448.

McGoldrick, D. (2006). Human rights and religion: The Islamic headscarf debate in Europe. Oxford: Hart Publishing.

Pew Research Center. (2007). Retrieved from http://www.peoplepress.org/2007/05/22/muslim-americans-middle-class-andmostly-mainstream/

Rashid, Ahmed. (1999). The Taliban: exporting extremism. Foreign Affairs (November-December) 78/6, 22-35.

John Simpson. Who are Thaliban, BBC NEWS-Asia, (2013, November 1). Retrieved from http://www.bbc.com/news/world-south-asia11451718

Zubaida, S. (2010). Contemporary trends in Muslim legal thought and ideology. In R. W. Hefner (Ed.), The New Cambridge History of Islam Volume 6: Muslims and Modernity: Culture and Society since 1800 (pp. 270-295). Cambridge: Cambridge University Press.

Samuel, K. L. H. (2013). The OIC, the UN, and counter-terrorism lawmaking: conflicting or cooperative legal orders? Sydney: Bloomsbury Publishing.

Saunders, D. (2012). "What Turns Some Western Muslims into Terrorists? The Causes of Extremism", excerpt from Chapter 2 of his book The myth of the Muslim tide: do immigrants threaten the West? New York: Random House. Retrieved from: http://dougsaunders.net/2013/04/muslim-immigrants-terroristsjihad-terrorism/

Stark, R. (1999). Secularization, R.I.P. Sociology of religion, 60(3), pp. 249-273.

Syed Muhammad Naquib al-Attas. (1991). The Concept of Education in Islam a Framework for an Islamic Philosophy of Education, Kuala Lumpur: International Institute of Islamic Thought and Civilization (ISTAC).

Syed Muhammad Naquib al-Attas. (1993). Islām and secularism. Kuala Lumpur: International Institute of Islamic Thought and Civilization (ISTAC). 
Yeşilada, B. A., \& Noordijk, P. (2010). Changing values in Turkey: Religiosity and tolerance in comparative perspective. Turkish Studies, 11(1), 9-27.

Yusuf Al-Qaradawi. (2006). Islamic awakening: Between rejection and extremism. USA: International Islamic Thought. 